\title{
Role of Reef-Building, Ecosystem Engineering Polychaetes in Shallow Water Ecosystems
}

\author{
Martín Bruschetti ${ }^{1,2}$ \\ 1 Instituto de Investigaciones Marinas y Costeras (IIMyC)-CONICET, Mar del Plata 7600, Argentina; \\ mbrusche@mdp.edu.ar \\ 2 Laboratorio de Ecología, Universidad Nacional de Mar del Plata, FCEyN, Laboratorio de \\ Ecología 7600, Argentina
}

Received: 15 June 2019; Accepted: 15 September 2019; Published: 17 September 2019

\begin{abstract}
Although the effect of ecosystem engineers in structuring communities is common in several systems, it is seldom as evident as in shallow marine soft-bottoms. These systems lack abiotic three-dimensional structures but host biogenic structures that play critical roles in controlling abiotic conditions and resources. Here I review how reef-building polychaetes (RBP) engineer their environment and affect habitat quality, thus regulating community structure, ecosystem functioning, and the provision of ecosystem services in shallow waters. The analysis focuses on different engineering mechanisms, such as hard substrate production, effects on hydrodynamics, and sediment transport, and impacts mediated by filter feeding and biodeposition. Finally, I deal with landscape-level topographic alteration by RBP. In conclusion, RBP have positive impacts on diversity and abundance of many species mediated by the structure of the reef. Additionally, by feeding on phytoplankton and decreasing water turbidity, RBP can control primary production, increase light penetration, and might alleviate the effects of eutrophication affecting supporting ecosystem services, such as nutrient cycling. They can also modulate cultural ecosystem services by affecting recreational activities (e.g., negative impacts on boating and angling, increased value of sites as birdwatching sites). Acknowledging the multiplicity of synergistic and antagonistic effects of RBP on ecosystems and linking changes in habitat structure, filter-feeding activities, and biodeposition to ecosystem services are essential for effective decision-making regarding their management and restoration.
\end{abstract}

Keywords: polychaetes; ecosystem engineers; reef-building; filter-feeding; ecosystem services

\section{Introduction}

After some controversy [1,2], the term "ecosystem engineer" is now widely accepted to denote the organisms that indirectly or directly modulate the availability of resources to other species via structural modifications of the environment [3]. Ecosystem engineers can modify the abiotic environment via their own physical structures (autogenic) or by transforming materials from one state to another (allogenic), with impacts on other species that are usually different [3,4]. In general, engineer-induced changes in the physical structure of the environment include the creation, maintenance, or destruction of habitats [5], all of which can affect the availability of resources such as refuge [6], light [7], humidity [8], organic matter [9], water [10], and heat [11]. These effects usually scale up to communities, ecosystems, and beyond [12].

Ecosystem engineering is widespread across ecosystems [13-15]. Classic examples include beavers that build dams and transform streams into ponds [16], trees in forests that regulate moisture and radiation [17], or ants that increase soil phosphorous due to transport of phosphorous-rich litter [18]. However, it is particularly critical in shallow, marine soft-bottoms $[19,20]$. These systems lack large abiotic three-dimensional structures but often host large biogenic structures that play critical roles in 
controlling abiotic conditions and resources (e.g., desiccation, salinity, temperature [21]). Examples in this regard are widespread and include mussels [22], oysters [23,24], and seagrasses [25]. At the community level, they usually increase organismal abundance and diversity $[23,26]$ by increasing habitat complexity and heterogeneity, thus favoring the settlement and survival of several species. At the ecosystem level, ecosystem engineering species can modify the availability or quality of nutrients and alter biogeochemical cycles [11], change the trophic resources in a food web [27], or modulate other resources such as living space (e.g., oysters [23,28], polychaetes [29]). For example, with their biogenic structures, ecosystem engineers decrease water flow leading to the passive deposition of organic matter in the benthic environment (e.g., oysters reefs [24]).

Reef building polychaetes (hereafter RBP) are also important engineers in soft bottoms [23, 28,29], though their effects are comparatively less well documented than others (shell-producing mollusks [6], seagrasses [30]). In this review, I illustrate that the ecosystem engineering impact of RBP can be extremely important for community structure and ecosystem functioning in these systems. These structure-forming species affect soft-bottom environments and their inhabitants via several mechanisms, including the alteration of water flow and bed-load sediment transport [31], the accumulation of organic matter between reefs [32], and the formation of a complex hard substrate habitat [33]. Moreover, the reefs themselves act as sediment traps ameliorating physical conditions by sediment accumulation and stabilization [34]. Through these and other effects on the abiotic environment, RBP increase biotic diversity and abundance $[26,35,36]$ and modify the distribution of infaunal and epifaunal organisms [37]. In addition to these community-level effects, RBP can affect ecosystem-level processes, mainly through their filter-feeding activities. Although filter feeding is not ecosystem engineering per se, it has extended consequences on the physical environment (i.e., increased water transparency) and, therefore, it can legitimately be viewed as an ecosystem engineering process [38].

This review focuses on the effects of filter-feeding polychaetes on physical structure and functions of shallow waters ecosystems and, specifically, on the impact of ecosystem engineering polychaetes that build reefs (Table 1). This work will contribute to understanding how an ecosystem engineer drives ecosystem processes and affects the quality of available habitat to other species, thus regulating community structure, ecosystem functioning, and ultimately ecosystem service provision. In shallow waters, there are several examples of RBP that modify the quality of the environment and, therefore, this is an appropriate system to evaluate this objective. The analysis is separated into different mechanisms of ecosystem engineering generated by RBP, such as hard substrate production, effects on water flow and sediment trapping, and impacts mediated by water filtering and biodeposition. Finally, landscape level effects of RBP are considered. 
Table 1. Examples of reef-building, ecosystem engineering polychaetes and their effect on structure and function of the ecosystems.

\begin{tabular}{|c|c|c|c|c|c|}
\hline Species & Depth/Area & Activity & Effect & References & Study Site \\
\hline \multirow{2}{*}{$\begin{array}{l}\text { Sabellaria alveolata } \\
\text { (Sabellidae) }\end{array}$} & \multirow{2}{*}{ Intertidal and subtidal $(0-10 \mathrm{~m})$} & Filter-feeding activity & Control of primary production & {$[39,40]$} & Mont-Saint-Michel (France) \\
\hline & & $\begin{array}{l}\text { Build reefs and provide } \\
\text { complex } 1 \text { habitat }\end{array}$ & Increase infaunal abundance and biodiversity & {$[33,41-44]$} & $\begin{array}{c}\text { Mont-Saint-Michel (France) } \\
\text { Central Tyrrhenian Sea (Italy) } \\
\text { English Channel, (France) } \\
\text { Bristol Channel (Wales, UK) } \\
\text { North Cornwall (England) }\end{array}$ \\
\hline \multirow[t]{2}{*}{$\begin{array}{l}\text { Sabellaria spinulosa } \\
\quad \text { (Sabellidae) }\end{array}$} & \multirow[t]{2}{*}{$\begin{array}{l}\text { Low intertidal zone and subtidal } \\
\qquad(0-10 \mathrm{~m})\end{array}$} & \multirow{2}{*}{$\begin{array}{l}\text { Form tubes with terrigenous } \\
\text { particles and can build reefs in } \\
\text { subtidal areas }\end{array}$} & $\begin{array}{c}\text { Increase surface heterogeneity } \\
\text { of the bottom and enlarges landscape } \\
\text { complexity }\end{array}$ & {$[45,46]$} & $\begin{array}{l}\text { Mediterranean Sea; Adriatic coast } \\
\text { (Italy) }\end{array}$ \\
\hline & & & $\begin{array}{c}\text { Acts as a physical barrier for storm waves and } \\
\text { as a storage of sandy sediments, mitigating } \\
\text { coastal erosion }\end{array}$ & [47] & Adriatic Sea (Italy) \\
\hline $\begin{array}{l}\text { Sabellaria wilsoni } \\
\quad \text { (Sabellidae) }\end{array}$ & $\begin{array}{l}\text { Coastal intertidal, shallow estuaries } \\
\text { and continental shelf }(0-100 \mathrm{~m})\end{array}$ & $\begin{array}{l}\text { Build reefs and provide } \\
\text { substrate }\end{array}$ & $\begin{array}{c}\text { Increase density, richness and diversity of } \\
\text { fauna, and } \\
\text { sediment organic matter }\end{array}$ & [48] & Amazon coastal region (Brazil). \\
\hline $\begin{array}{l}\text { Serpula vermicularis } \\
\text { (Serpulidae) }\end{array}$ & Intertidal to sublittoral zone $(0-20 \mathrm{~m})$ & $\begin{array}{c}\text { Increase of substratum } \\
\text { complexity forming small reefs }\end{array}$ & Increase diversity and abundance of infauna & [26] & Loch Creran (Scotland) \\
\hline $\begin{array}{l}\text { Hydroides dianthus } \\
\text { (Serpulidae) }\end{array}$ & Shallow estuaries & Create substrate & $\begin{array}{l}\text { Provide benthic habitat suitable for the } \\
\text { settlement of jellyfish polyps }\end{array}$ & [49] & Northern Yellow Sea (China) \\
\hline \multirow{4}{*}{$\begin{array}{l}\text { Ficopomatus enigmaticus } \\
\text { (Serpulidae) }\end{array}$} & \multirow{4}{*}{$\begin{array}{l}\text { Intertidal and subtidal of shallow } \\
\text { estuaries, ports and marinas }(0-4 \mathrm{~m})\end{array}$} & Filter-feeding activity & $\begin{array}{l}\text { Control of phytoplankton biomass and } \\
\text { turbidity }\end{array}$ & {$[50-52]$} & $\begin{array}{l}\text { Mar Chiquita lagoon (Argentina), } \\
\text { Zandvlei (South Africa). }\end{array}$ \\
\hline & & \multirow[t]{2}{*}{ Supply of substrate } & $\begin{array}{l}\text { Provide benthic habits suitable for the } \\
\text { settlement of amphipods, crabs, oysters, } \\
\text { gastropods, polychaetes and macro-algae }\end{array}$ & {$[34,53,54]$} & $\begin{array}{c}\text { Mar Chiquita lagoon (Argentina), } \\
\text { Californian estuary, Elkhorn Slough } \\
\text { (EEUU). }\end{array}$ \\
\hline & & & $\begin{array}{l}\text { Augments the substrate and the number of } \\
\text { prey for shorebirds }\end{array}$ & [29] & Mar Chiquita lagoon (Argentina). \\
\hline & & $\begin{array}{l}\text { Biodeposition: a portion of the } \\
\text { material filtrated is rejected to } \\
\text { the water as feces or } \\
\text { pseudofeces }\end{array}$ & Increase sedimentary organic matter & [55] & Mar Chiquita lagoon (Argentina) \\
\hline $\begin{array}{l}\text { Boccardia proboscidea } \\
\quad \text { (Spionidae) }\end{array}$ & $\begin{array}{l}\text { Intertidal area. Sandy beaches and } \\
\text { stony rocks of consolidate loess } \\
\qquad(0-1 \mathrm{~m})\end{array}$ & $\begin{array}{l}\text { Build ephemeral biogenic reefs } \\
\text { in sewage areas }\end{array}$ & $\begin{array}{l}\text { Excludes all sessile fauna and flora in rocky } \\
\text { inter-tidal communities }\end{array}$ & {$[36,56,57]$} & Mar del Plata (Argentina) \\
\hline \multirow[t]{2}{*}{$\begin{array}{l}\text { Lanice conchilega } \\
\text { (Terebellidae) }\end{array}$} & \multirow{2}{*}{$\begin{array}{l}\text { From lower intertidal of estuaries } \\
\text { and coastal marine }(0-1 \mathrm{~m}) \text { to } \\
\text { bathypelagic areas }(1900 \mathrm{~m})\end{array}$} & Build biogenic emergent reefs & $\begin{array}{l}\text { Increase refuges for fishes and benthic } \\
\text { biodiversity }\end{array}$ & {$[58-60]$} & $\begin{array}{l}\text { German Wadden sea, Gower } \\
\text { peninsula (South Wales), } \\
\text { Boulogne-sur-Mer (France) }\end{array}$ \\
\hline & & Filter-feeding activity & Control of phytoplankton biomass & {$[40,61]$} & Mont-Saint-Michel (France) \\
\hline
\end{tabular}


RBP as Ecosystem Engineers. Geographic Distribution, Habitat, Size, and Local Densities

Several species of RBP play fundamental ecological roles, particularly when they are established in high densities (Table 1, Figures 1 and 2). RBP species are present in multiple marine systems worldwide, such as sandy beaches [36], coastal marinas [50], coastal lagoons [62], and estuaries [63] (Figure 1). Most RBP species inhabit soft bottoms [58,62,64], but they can also be found in intertidal $[32,65]$ and subtidal hard bottoms [26]. Associations of individual tube-building polychaetes can lead to large reefs of cemented sand grains (e.g., Sabellarids [66]) or calcareous secretions [67,68].

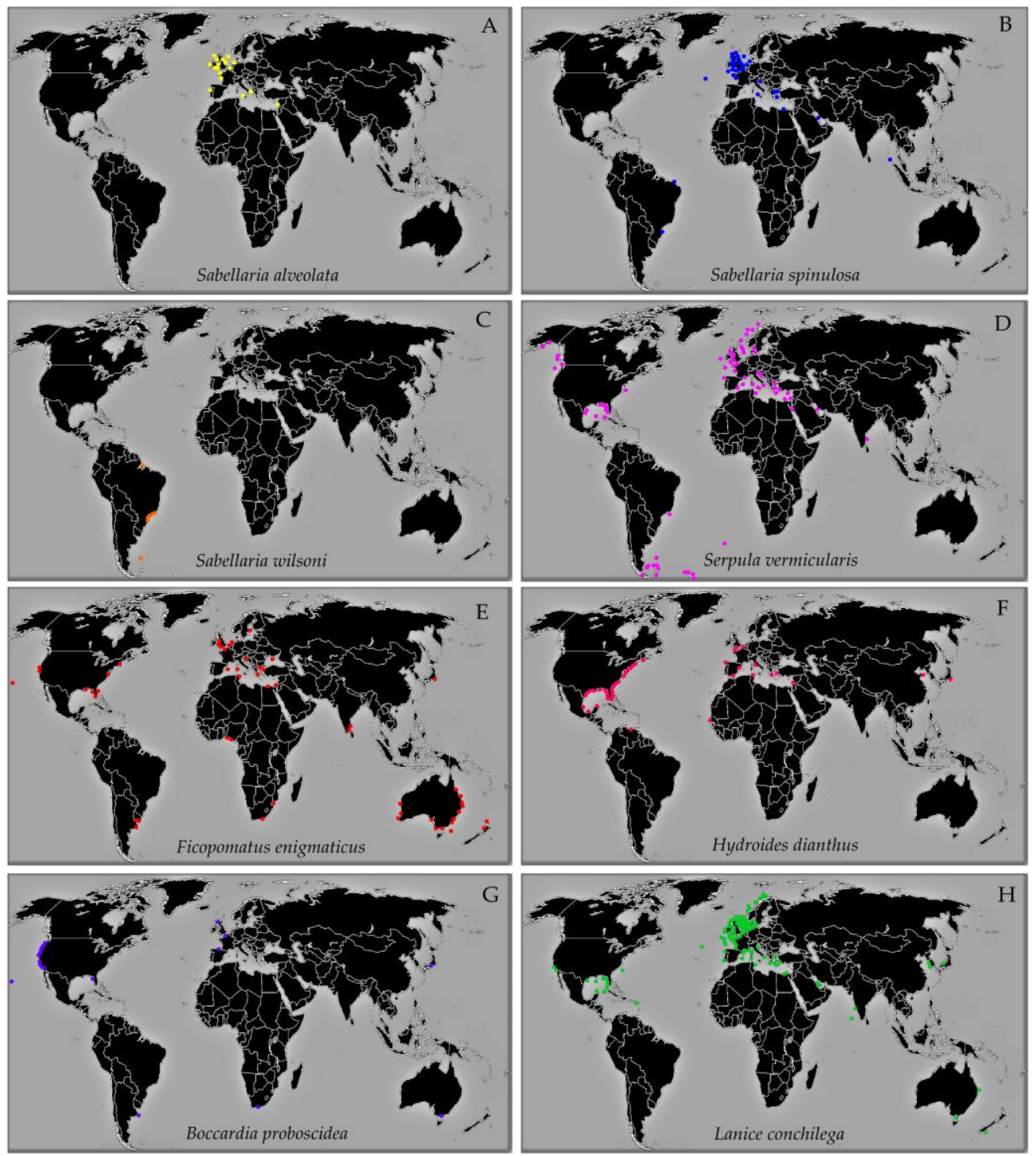

Figure 1. Maps showing the geographical distribution of the reef-building polychaetes (RBP). Point occurrence data were extracted from the Ocean Biogeographic Information System (OBIS) database (https://www.iobis.org) on 7 August 2019. Occurrence data were compared with the World Register of Marine Species (WoRMS) database (https://www.worms.org/, downloaded on 7 August 2019) and from The Marine Life Information Network, Marine Biological Association of the United Kingdom (https://www.marlin.ac.uk). (A) Sabellaria alveolata, (B) Sabellaria spinulosa, (C) Sabellaria wilsoni, (D) Serpula vermicularis, (E) Ficopomatus enigmaticus, (F) Hydroides dianthus, (G) Boccardia proboscidea, (H) Lanice conchilega. 


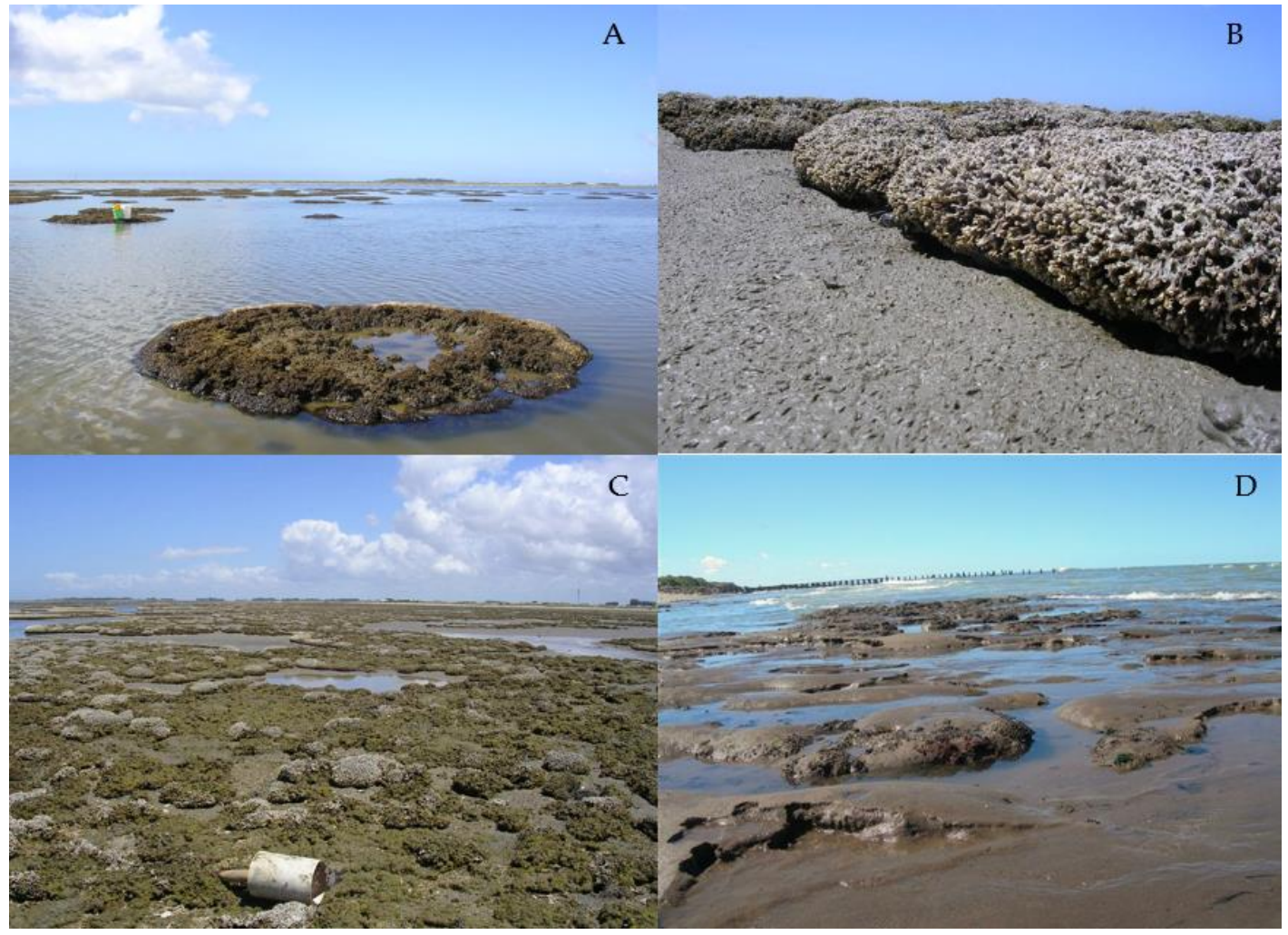

Figure 2. Photographs showing RBP. Reef of Ficopomatus enigmaticus in Mar Chiquita coastal lagoon (Buenos Aires, Argentina) showing different shapes: (A) circular and (C) platform-type. (B) tubes of F. enigmaticus at low tide. (D) Reef of Boccardia proboscidea in sewage-impacted area in Mar del Plata coast (Argentina). Photo credit: A, B, C: C.M. Bruschetti; D: M.L. Jaubet.

In Europe, two species of the genus Sabellaria are documented: Sabellaria alveolata and S. spinulosa. S. alveolata is a polychaete that builds one of the most extensive reef formations (Figure 1A) and covers large areas in the lower elevations of tidal flats of the Northeastern Atlantic (from Scotland to Morocco [33,65], including Wales, Ireland, and England [41,44], English Channel in France [42], and Portugal [33]) and the Mediterranean sea [69]. S. alveolata builds a variety of reef types (mushrooms, balls, barriers, coalescent structures) and platforms [42]. The balls can be up to $1 \mathrm{~m}$ tall and coalesce to form flats of up to $2 \mathrm{~m}$ height and several hectares in size [66]. The largest of these formations is located in the Mont Saint-Michel Bay (France) with polychaete densities of up to 60,000 ind $\mathrm{m}^{2}$ [70] and an extension of 300 ha [71]. In the Mediterranean sea (Ostia, Rome), a continuous reef flat covers about $48,000 \mathrm{~m}^{2}$ and extends for almost 1 linear $\mathrm{km}$ parallel to the coastline, whereas the reefs and isolated concretions made by this polychaete occupy about $275,000 \mathrm{~m}^{2}$ (mainly in the midlittoral-upper-infralittoral zone [72]). In England, reefs are more abundant in the south (English Channel) and west coasts, with records of isolated forms in the southeast and east coasts [73]. It has also been found on hard substrates on exposed coasts with moderate to considerable water movement, where sand is available for tube construction (typically, in the lower third of the shore, but also in the shallow sub-tidal [73]).

Sabellaria spinulosa reefs are smaller than S. alveolata, and it is found in subtidal and low intertidal areas of the European coast (Figure 1B). It is a solitary species that can also be found in small groups. However, under favorable conditions, it forms reefs up to several $\mathrm{cm}$ high [45]. The reefs of S. spinulosa occur in locations around the British Isles [45,71]. In the North Atlantic coast, its aggregations usually range between 4500 and 12,000 ind $\mathrm{m}^{-2}$. However, S. spinulosa tube density can reach high values, approximately 37,000 ind $\mathrm{m}^{2}$ [45]. S. spinulosa modifies, maintains and creates habitat, as already observed in various studies involving the congeneric species S. alveolata. Other sabellariid considered 
as an ecosystem engineer is the RBP Sabellaria wilsoni (Figure 1C, [48]). This polychaete inhabits rocky outcrops in the shallow infralittoral and lower mesolittoral of sandy beaches in the Amazon coast region, Brazil $[48,74]$. In these areas, $S$. wilsoni builds two types of reefs: Ball and platform with an average height of $10.5 \mathrm{~cm}$ and $13 \mathrm{~cm}$, respectively [48].

The serpulid Serpula vermicularis usually occurs as a solitary species but forms massive reefs at three sites in north-west Europe (Ardbear Lough and Killary Harbour in Ireland, Loch Creran in Scotland; Figure 1D), which can be up to $50 \mathrm{~cm}$ height and $60 \mathrm{~cm}$ width [39,75]. The area occupied by reef has been estimated at 108 ha and the coverage ranged from $3 \%$ to $25 \%$ in Loch Creran [75]. These biogenic reefs increase local habitat complexity in intertidal and sublittoral areas $(0.2-16.8 \mathrm{~m}$ of deep [75]).

Other serpulid with high impact on the environment is Ficopomatus enigmaticus. This polychaete is cosmopolitan (Figure 1E) and has successfully invaded several estuaries and coastal lagoons across the world (South Africa [50], New Zealand [76], Japan [77], England [78], Argentina [68], Italy [79], Uruguay [80], USA [53]). In the subtidal and intertidal flats of Mar Chiquita coastal lagoon (Buenos Aires, Argentina), F. enigmaticus builds large circular reefs up to $7 \mathrm{~m}$ diameter, and many neighboring reefs have coalesced into large platforms [62] (Figure 2A-C). Currently, its density continues to increase reaching 370 reef ha $^{-1}$ [31]. Google Earth satellite imagery showed that the reefs cover large areas of the lagoon (14.5\% of the lagoon or $6.67 \mathrm{~km}^{2}$; Bruschetti, unpublished data). The reefs grow $1.6 \mathrm{~cm}$ month $^{-1}$, and rapid increases in reef density $(24.3 \%)$ and size $(66.8 \%)$ occurred in the last 60 years [62]. This invasive ecosystem engineer has enhanced sedimentation at the scale of the whole estuary, with concomitant reductions in water depth and long-term changes in hydrological and sedimentary dynamics [31]. The Zandvlei Estuary (Cape Town, South Africa) is a system that has been highly modified by human activities (e.g., industry, housing, agriculture, and forestry) and it has also been invaded by F. enigmaticus $[50,63]$. The major human-induced physical changes in this estuary have been the development of a complex canalized marina system, where F. enigmaticus found a suitable substrate (concrete walls) to attach to and build its reefs [50]. The standing stock of F. enigmaticus in this estuary increased 365\% in 26 years (from $13.69 \mathrm{t}$ in 1986, to $50.03 \mathrm{t}$ in 2012), due both to increase in total area invaded (from $5080 \mathrm{~m}^{2}$ to $6138 \mathrm{~m}^{2}$ ) and standing stock per $\mathrm{m}^{2}$ [63].

Hydroides dianthus is a native RBP (Figure 1F) of the eastern coast of North America that is widely distributed in open coastal areas as well as in the partly brackish waters of bays, lagoons, and ports [81]. $H$. dianthus larvae preferably settle in bare spaces, and their settlement is markedly gregarious [82]. Consequently, $H$. dianthus is found in groups of tubes that provide microhabitats to several groups of other invertebrates. It is an invasive species in the Orbetello lagoon, Italy, where it builds relatively small reefs (less than $1 \mathrm{~m}$ diameter) [79] and in Tokyo Bay, where it has negative economic effects as fouler of port and mariculture facilities and infrastructure [49].

The spionid polychaete Boccardia proboscidea is a filter-feeder native of the western coast of North America (from British Columbia to Baja California [83]) that has also invaded several sites worldwide (Hawaii [84], Japan [85], Australia [86], Europe [87], South Africa [88]; Figure 1G). Although this species has not been previously reported as a reef builder, it invaded sewage-impacted intertidal areas and built massive reef-like structures in the South-West Atlantic (Mar del Plata: $38^{\circ} \mathrm{S}, 57^{\circ} \mathrm{W}$ and Quequén: $38^{\circ} \mathrm{S} ; 58^{\circ} \mathrm{W}$ Argentina, Figure 1D; $\left.[32,89]\right)$. These invasive reefs covered almost the entire impacted site, reaching a density up to $1,650,000$ ind $\mathrm{m}^{-2}$ [57].

The terebellid tubeworm Lanice conchilega is an ecosystem engineer with a relatively short life span from 1 to 3 years [64]. This sessile tube-building worm is ubiquitous along European coasts and inhabits sandy and muddy sediments from the shallow intertidal to depths up to $1900 \mathrm{~m}$ (Belgian coast [90], German Wadden Sea, South Wales, France [58]; Figure 1H). L. conchilega reefs are common along the French coast of the English Channel (central part of Mont Saint-Michel and the lower section of the tidal flats) covering ca. 25,000 ha [91]. Lanice conchilega forms biogenic tube aggregations that can be considered reefs when densities are high [58]. These aggregates reach at densities as high as 20,000 ind $\mathrm{m}^{-2}$ during recruitment and protrude up to $16 \mathrm{~cm}$ above the sediment surface [90]. 


\section{Engineering Impact by RBP}

\subsection{Reefs as Living Space}

Organisms that build structures add heterogeneity to soft-bottom habitats that are often deprived of large structural elements. These structures themselves can be hard substrate for sessile epibenthic organisms that cannot settle on the soft-bottom. Moreover, the complex three-dimensional structure of reefs provides interstitial space where the impacts of predators, physical, and physiological stress can be reduced [21-24].

Polychaete reefs provide hard substrates and interstitial space, thus increasing habitat heterogeneity and altering the diversity [58,74], composition [53], abundance [92], and distribution of the epibenthic species $[33,93]$. Biogenic reefs can be seen as biodiversity hotspots because they have higher species diversity than surrounding habitats [70]. For example, Sabellaria alveolata reefs in Mont Saint-Michel Bay host a distinctive assemblage made of a mixture of species from several environments (i.e., hard substrates, sandy bottoms, mudflats, subtidal, and terrestrial habitats [33]). Macrofaunal species richness and densities are six and 20-fold higher in S. alveolata reefs at this site [33,37]. In general, the benthic assemblages associated with the $S$. alveolata reefs are rich hard substrates fauna (i.e., sessile species such as bivalves, barnacles, other tube-building polychaetes) and poor in soft substrate fauna (i.e., mobile species, such as free-living polychaetes; [37,72]). Differences in reef architecture and status (i.e., ball-shaped, degraded, or platform) account for variation in macrofaunal assemblages [70]. Overall, species richness was found to be higher in degraded reefs than in the other forms, likely because the number of tubes in degraded S. alveolata reefs is lower and the surface more irregular, thus affecting hydrodynamics, sediment trapping, and the settlement of larvae and post-larvae $[69,70]$.

In Amazonian beaches, the macrofauna of Sabellaria wilsoni reefs is completely different from that of the adjacent sandy sediments, showing a remarkably higher density (300-fold higher), as well as differences in composition, richness, and diversity (up to threefold higher). Most (91\%) of the taxa in these beaches occur in reefs. Only two taxa occurred both in reefs and in their surrounding sandy sediments [74]. At ecosystem level, these RBP augment the levels of biodiversity in an otherwise low-diversity soft-bottom system [33,74], which highlights their role as critical ecosystem engineers in this system.

Similarly, the invasive reef-building polychaete Ficopomatus enigmaticus been shown to increase the abundance and diversity of other organisms by creating novel habitats on soft-bottom sediments worldwide [34,63]. In the Zandvlei estuary (South Africa), F. enigmaticus reefs show $60 \%$ more invertebrate species than their surrounding sandy bottoms [63]. A great number of epifaunal and sessile species (e.g., snails, bryozoans, and crabs) were favored by the RBP invasion. This invasion has also caused a ca. 200-fold increase in invertebrate biomass (including F. enigmaticus [63]). In Mar Chiquita lagoon (Argentina) the invasive reefs of F. enigmaticus strongly increased the abundance of macrofaunal species, with 100-, 400-, and 600-fold increases in the densities of the invasive amphipod Melita palmata, crabs Cyrtograpsus angulatus (adults), and the gastropod Littoridina parchappi, respectively $[29,31,94]$ and relative to nearby open mudflats. Recruits and juveniles of $C$. angulatus also use these biogenic structures as nursery habitats. The total number of juveniles and recruits of C. angulatus at non-reef nursery sites (e.g., shell beds) is a just $2.7 \%$ of the total number estimated to inhabit F. enigmaticus reefs [94]. A single reef of F. enigmaticus (diameter approximately $2.5 \mathrm{~m}$ ) can host approximately 250,000 invasive amphipods [95], 40 C. angulatus adults [34] and $1.6810^{10}$ recruits and juveniles of this species [94]. In California, none of the species associated to F. enigmaticus occur exclusively in reefs but their abundance therein is threefold higher than in surrounding mudflats [53]. The reefs of these species can also increase on macroalgal biomass via the provision of hard substrate (40-fold increases in the biomass of the red algae Polysiphonia subtilissima in Mar Chiquita lagoon [54]).

Although the aggregations of Lanice conchilega do not necessarily fit to the concept of reef, high densities of these tubeworms create mounds that change soft-bottom topography and have effects on fauna that are analogous to those of typical polychaeta reefs [58]. L. conchilega alters macrofaunal 
composition and positively affects its density and species richness both in intertidal [35] and subtidal settings [96]. Although the aggregations of L. conchilega are ephemeral, they can increase the number of macrofaunal species by $20 \%$ and $140 \%$ (12 to 29 ) in intertidal [35] and subtidal sandflats areas [64,90], respectively. In addition, the richness of macrofauna in L. conchilega aggregations is $30 \%$ and $70 \%$ higher than in surrounding intertidal and subtidal areas, respectively [90]. Clearly, the impact of L. conchilega on community parameters is greater in the subtidal zone where the reefs are more stable [35]. The organisms that positively associate with this polychaete are bivalves, amphipods (16 species), and crabs. In general, the dense aggregations of this species directly and positively increase the abundance of predatory infauna (e.g., crabs, polychaetes) by giving them shelter [96]. Five species were exclusively found in L. conchilega aggregations (sea anemone, polychaetes, and amphipods). In addition, such aggregations provide a primary settlement surface for larval and post-larval benthic organisms [35].

Polychaete reefs as also provide food and resting areas for birds (due to reduced submergence periods). Bird counts on F. enigmaticus reefs in Mar Chiquita lagoon is 2.5 times higher than in surrounding mudflats. Migratory shorebirds (plovers) use reefs as foraging sites, while non-migratory birds (e.g., cormorants, kelp gulls, brown-hooded gulls, swans, and storks) use reefs as resting areas [29]. Similarly, L. conchilega aggregations are used as feeding and resting sites by shorebirds in the Wadden Sea [28]. Bird densities in flats with L. conchilega aggregations were found to be six times higher than in bare mudflats [28]. Four out of seven waterbird species at this site (oystercatcher, curlew, redshank, common gull) preferred flats with either high densities or low densities of polychaete. Common gulls preferred areas with low densities of L. conchilega, whereas oystercatchers preferred Lanice flats [28]. Waders mainly foraged on the accompanying fauna of the L. conchilega and gulls on L. conchilega itself. In sum, the physical presence of Lanice conchilega and F. enigmaticus reefs increase resources (i.e., prey, refuge) to birds.

RBP usually have net positive effects on species richness, but this is not necessarily positive for their ecosystems as a whole. Invasive RBP can increase abundance and diversity of native species $[29,34,94]$ but also create conditions for additional invasions. Clearly, invasive ecosystem engineers can create novel environmental conditions that may represent an opportunity for the establishment and spread of new exotic species in an otherwise unsuitable habitat [97]. For instance, some invasive engineers may facilitate other invasive species by providing them with an otherwise limiting physical resource, such as a hard, three-dimensional substrate in an unstructured soft bottom [53,95]. This is likely the case of F. enigmaticus, whose structurally complex reefs seem to have facilitated the establishment and spread of the amphipod Melita palmata in Argentinean [95] and European estuaries [78,79]. Because of its explosive population growth and large population size, this exotic amphipod can potentially reconfigure food webs, thus affecting important ecosystem functions (e.g., secondary production [95]).

There are also circumstances when three-dimensional biogenic structures decrease the diversity and abundance of macrofaunal species. Significant reductions in density, richness, and diversity of macrofaunal organisms were observed in sewage-impacted sites of Mar del Plata, Argentina, after the establishment of Boccardia proboscidea reefs [36]. In these case, the reefs replaced a relatively more rich, mussel- and algal-dominated community by occupying all the available space in intertidal consolidated sediment platforms ([32,36]; Figure 2D). The development of anoxic conditions in these reefs is likely an important filter for macrofaunal colonization [32,36]. Moreover, Boccardia reefs are built with sand, which makes them unsuitable for the attachment of sessile invertebrates and macroalgae [98]. The relatively rich communities that formerly characterized this site are today replaced by nearly monospecific assemblages of the invasive polychaete B. proboscidea.

\subsection{Sediment Mediated Effects}

As in salt marshes [99], seagrass meadows [100], and bivalve beds [101], polychaete reefs trap sediment. The three-dimensional complexity of reef surfaces alters boundary layer flows and enhances the settlement retention of suspended and bedload-transported particles [102]. Sediment trapping 
in the interstitial space of reefs allows their colonization by sediment-dependent, infaunal species. The reefs of tube-building worms (e.g., Sabellaria spp., Lanice conchilega, Ficopomatus enigmaticus) are known to act as efficient traps for sediment [34,47], stabilizing them and generating favorable conditions for the infauna [103].

The reefs of Ficopomatus enigmaticus host a high abundance of detritivores (82\% of the total organisms [53]). This may be the result of high local availability of organic matter in interstitial sediments through sediment trapping and accumulation of pseudofeces [55]. Several organisms inhabit the mud between the tubes of reefs in Mar Chiquita coastal lagoon. The free-living polychaetes Laeonereis acuta, Nephtys fluviatilis, and Alitta succinea [29] are favored by the presence of sediments and shelter in these reefs. In addition, free-living polychaetes from a soft-bottom intertidal system were also found living in Sabellaria alveolata reefs $[43,70]$. In this case, the presence of vacant, sand-filled tubes in the reef favored the occurrence of infaunal organisms.

Analogously, the terebellid polychaete Lanice conchilega in the North Sea altered sedimentological properties [104]. Reefs of L. conchilega affected two key attributes of the coastal environments: Coastal protection and sedimentary processes. The reefs increased up to $14 \%(-0.95$ to $0.14 \mathrm{~cm})$ of the mean deposition rate, making the areas with reefs shallower (54\%) than bare sand areas without them. These aggregations affect the erosion and accretion processes, increasing coastal resilience to hydrological impacts [60]. However, when the polychaetes are in low densities, sediment is destabilized [105], mounds disappear, and the susceptibility of the habitat for further disturbance increases [106]. Sabellaria wilsoni reefs create a mosaic of sediment types in Brazilian tropical sandy beaches. Indeed, the percentages of silt, clay, medium sand, and organic matter are seven, two, 0.6, and seven times higher, respectively, on reefs than in surrounding sandy areas [74]. In this case, sediment characteristics of reefs result from a combination of passive sediment trapping and the size-selective behavior of worms when collecting particles for tube building [74]. A higher proportion of finer sediments (silt and clay) likely support a higher number of nematoda on the reefs ( $10 \%$ more) compared to surrounding sandy sediments. Meiofaunal communities varied with reef shape, showing higher richness and density in ball-shaped than platform reefs, even though there were no differences in environmental variables between the two types of reefs [48]. Changes in abiotic factors, such as granulometry and organic matter content of the sediment, leads to higher diversity and composition of the infauna in the reefs relative to adjoining, non-reef habitats [48].

Sabellaria spinulosa builds sandy reefs in nearshore areas of the Adriatic Sea (southern Italy) where the action of waves provides clastic materials for reef formation. This species selects sand based on its grain size and shape and not its composition. Seasonal variation in the sediment characteristics of these reefs occur in association with reef growth and degradation periods related to physical processes (e.g., storms and wave action [47]). S. spinulosa traps and concentrate sediment particles, modifying the physical environment along the Apulian coast [45].

\subsection{Effects Mediated by Filter Feeding}

As filter-feeding bivalves $[107,108]$, many RBP affect the seston of shallow waters (i.e., estuaries and coastal lagoons) by removing large amounts of suspended particulate matter (i.e., phytoplankton and detritus) from the water column $[50,109,110]$. This increases light penetration (i.e., reduces turbidity) and can therefore increase the production of benthic primary producers. Although bivalve filtration has been largely studied, [111-113], much less is known about the polychaete filtration (but see $[50,51])$.

Filter feeding by Ficopomatus enigmaticus in Mar Chiquita coastal lagoon improves water quality, removes phytoplankton and reduces suspended particle loads [51,52,114]. F. enigmaticus decreased water turbidity and chlorophyll $a$ concentration by nearly by $50 \%$ per day in field mesocosms [51]. Considering current reef densities, the total volume of the lagoon, and the clearance rate as estimated in situ (4.34 $\mathrm{L} \mathrm{h}^{-1} \mathrm{~g} \mathrm{DW}^{-1}$ [103]), F. enigmaticus reefs would filter all the water volume of the lagoon in just $144 \mathrm{~h} \mathrm{[114]}$. This suggests that this polychaete is strongly affecting the overall estuarine productivity 
and the carbon sources available to higher trophic levels. In addition, this invasive polychaete can change the composition and particle size in the seston community [52], leading to higher water transparency. Clearance rates are different between fractions of chlorophyll, being higher for centric (removed $76 \%$ to initial stock) and pennate diatoms (removed 58\%) compared with other components of the microphytoplankton. The genera that are more affected by F. enigmaticus feeding are the pennate diatoms Amphiprora, Amphora, Asterionellopsis, Cylindrotheca, Gomphonema, Navicula, Nitzschia, and Pleurosigma, and the centric diatoms Biddulphia, Chaetoceros, Coscinodiscus, Licmophora, and Thalassiosira. F. enigmaticus preferentially removes larger phytoplankton (between 5 and $20 \mu \mathrm{m}$ ), which indicates that this invasive polychaete promotes shifts in the size and composition of the planktonic community [52].

Sabellaria alveolata is a ciliary filter feeder that is undergoing anthropogenic pressures (aquaculture, fishing-driven trampling [115]). In macrotidal shellfish ecosystems, these RBP compete for food with cultivated filter feeders (e.g., oysters Crassostrea gigas, Ostrea edulis and mussels Mytilus edulis [39]). In Mont-Saint-Michel Bay, the large biogenic reefs are a significant biological filter and play an important ecological role [39]. Although the reefs filter $0.4 \mathrm{~m}^{3}$ water $\mathrm{m}^{-2}$ day $^{-1}$, this clearance rate is lower than the rates found in dense mussel beds $\left(100 \mathrm{~m}^{3} \mathrm{~m}^{-2}\right.$ day $\left.^{-1}\right)$ that surround the study area.

Greater light penetration enhances by microphytobenthic $[116,117]$ and submerged macrophyte production [108]. Rather than being inconsequential, this effect likely plays an important role given the importance of microphytobenthic diversity and its relationship with ecosystem functioning [118]. The productivity of benthic microalgae in shallow estuaries and lagoons is high, and depending on water depth and transparency, it can reach values closer or higher than phytoplankton production [119]. Because of its important contribution to the productivity of shallow waters, the microphytobenthos is often called the "secret garden" [120]. Benthic microalgae are an important food source for deposit-feeding macrofauna (e.g., nematodes and polychaetes [121], crabs [122]), and therefore these communities could be largely benefited by increased light penetration. Therefore, filter-feeding RBP are expected to increase microphytobenthic production and the relative importance of grazing over detritivory as pathways for material cycling in the benthos.

\subsection{Biodeposition}

A large portion of the suspended material ingested by filter feeders is eliminated as feces [123] or packed in mucus and discarded as pseudofeces without having passed through the digestive tract [124]. Feces and pseudofeces expelled by filter-feeders are mucus-bound aggregates, which settle down up to 40 times faster than non-aggregated particles from which they are formed (e.g., bivalves [125]). Depending on the energy of the water flow, these aggregates can remain settled on the bottom or entrain into transport [126]. Biodeposition can be an important component of sedimentation and a significant source of nutrients to bottom sediments [126].

Ficopomatus enigmaticus releases both pseudofeces and feces in shallow waters [55]. The organic matter content of these aggregates is 21-fold higher than that of the sediment between reefs. In areas of low hydrological energy, biodeposition by this species accounts for an $18 \%$ increase in the organic matter content of superficial sediments [55]. By increasing the delivery rate of organic matter to bottom sediments, this species modulates its availability to other organisms and enhances the benthic-pelagic coupling [55]. Pseudofeces production has also been documented in sabellarids [127], though their potential for sedimentation enrichment of bottom sediments has not been assessed yet. However, considering the high density and biomass of S. alveolata and S. spinulosa [33,45], it is reasonable to expect that biodeposits will form a significant component of the organic matter in their adjoining benthic environments.

\subsection{Extended Engineering Influences}

The engineering effects of RBP can extend well beyond the reef environment and its immediate surroundings. The occurrence an extent of such influences will ultimately depend on the abundance and size of reefs [60]. Reefs are obstacles for water flow increasing sedimentation rates in their 
surrounding environment and beyond. This is the case of Lanice conchilega in the North Sea [104]. Mean sedimentation rates are up to $14 \%$ higher when aggregations of this species are present, which makes these areas 54\% shallower than areas without aggregations. Collectively, these aggregations affect erosion and accretion processes and increase coastal resilience to hydrological impacts [60]. Indeed, when the density of these polychaetes decrease, sediments are destabilized [105], depth increases, and the sedimentary habitat becomes more susceptible to further disturbance [106].

In the same vein, the reefs of Ficopomatus enigmaticus reduce water flow and bedload sediment transport in Mar Chiquita lagoon, leading to the accumulation of finest sediments on top of them and the predominance of coarse sediments at their upstream side [31]. The reefs of F. enigmaticus accumulate $107 \mathrm{~kg}$ of the sediment per $\mathrm{m}^{-3}$, and the total amount of sediment retained by reefs in the lagoon is estimated at 339 tons [31]. Because of their considerable density and cover, the reefs made by this species are likely to have altered the overall hydrology and sedimentary dynamics at the lagoon. Ficopomatus enigmaticus reefs can also indirectly affect the infaunal assemblages in surrounding soft-bottoms by hosting predators or detritivores that feed on them or physically disturb the sediments [53]. In Mar Chiquita lagoon, increased predation by crabs on epifaunal and infaunal invertebrates allowed important changes in mudflat assemblages within the $20 \mathrm{~cm}$ halo of fringe around the reefs [34]. In addition, the sediment accumulated between the reefs modified the distribution and abundance of infaunal organisms. F. enigmaticus reefs significantly affected the distribution of meiobenthic and macrobenthic organisms in the surrounding mudflat [34]. For example, abundances of the capitellid polychaete Heteromastus similis were significantly lower in the surrounding area of the Ficopomatus reefs than in areas apart from reefs. Several macrobenthic species, including the polychaetes Laeonereis acuta and Nephtys fluviatilis, negatively responded to the presence of reefs, in particular when the treatment included an exclusion of the crab Cyrtograpsus angulatus [34]. Similar spatial influences of these RBP on infaunal assemblages by this polychaete were observed in a Central California estuary, where reefs support high densities of native shore crabs [53].

Lanice conchilega also has extended engineering influences on other organisms, such as the flatfish Pleuronectes platessa, which is three times more abundant when their aggregations are present. This is because they provide an irregular environment that improves the nursery function of a highly dynamic coast [59].

\section{Effect of the RBP on Ecosystem Services}

Overall, it is clear that these ecosystem-engineering polychaetes can regulate community composition and ecosystem functioning [50,96]. These interactions can have consequences for the provision of ecosystem services [128,129]. There are multiple ways in which RBP can affect ecosystem services.

\subsection{Regulating Services}

Coastal erosion has become a serious problem worldwide not least because of sea level rise and the increased intensity and frequency of extreme climate events in the context of ongoing climate change [130]. There are some polychaetes capable of converting large volumes of sand in biogenic reefs structures and, in so doing, they can stabilize sediments and reduce erosion. For instance, sabellariid reefs play an important role as a physical barrier for storm waves and currents, and they can temporarily store sandy sediments (impounding as much as $96 \%$ of the sediment that washes over them [131]), thus mitigating coastal erosion [45]. In some circumstances, preserving and restoring RBP might be an environmentally friendly and cost-effective alternative to the installation of hard coastal infrastructure (e.g., groins, seawalls, breakwaters) for coastal erosion management [132,133]. Conversely, increased sedimentation due to the establishment of invasive RBP might be a serious problem. For example, Ficopomatus enigmaticus reefs have increased sedimentation and reduced water depth in Mar Chiquita lagoon [31], reducing its navigability. Moreover, these invasive RBP can also colonize seawater pipelines obstructing water flow (e.g., the cooling system of an oil refinery in 
Montevideo, Uruguay [80]). Therefore, a full assessment of the benefits and costs generated by the $\mathrm{RBP}$ is necessary when considering them for coastal ecosystem management.

\subsection{Cultural Services}

Reef-induced sedimentation can affect recreational aquatic activities in shallow waters, such as boating, kitesurfing, fishing, and rowing. Besides sedimentation, the reefs themselves may be obstacles for navigation, as is the case of F. enigmaticus reefs in Mar Chiquita coastal lagoon. As reef cover increased in this area, navigation has largely become limited to airboats.

Birdwatching is an increasingly popular recreational activity worldwide. By providing food and resting areas for shorebirds, RBP can improve the value of these environments as birdwatching sites. In the Wadden Sea and Mar Chiquita coastal lagoon, areas with RBP (L. conchilega and F. enigmaticus, respectively) show a higher abundance and diversity of shorebirds than areas without reefs [28,29]. Hence, in both cases RBP increase the recreational and aesthetic value of the environments they inhabit.

\subsection{Supporting Services}

Supporting services are the basis for nutrient and energy flows, and include primary productivity, nutrient and water cycling, and habitat structure in marine and coastal ecosystems [128]. Benthic filter feeders such as RBP are a strong trophic link between the pelagic and benthic realms and, consequently, regulate their nutrient stocks, biotic production, and composition. Nitrogen and phosphorus are fixed by primary producers in the water column. This biomass of phytoplankton constitutes the base of pelagic and benthic marine food webs [134]. Filter-feeding polychaetes (e.g., F. enigmaticus; S. alveolata; S. spinulosa; L. conchilega; Table 1) play a key role in ecosystem functioning by filtering suspended particles from the water column $[51,109,127]$ and releasing them in the benthic environment as feces and pseudofeces [55]. Deposit feeding invertebrates (e.g., crabs, free-living polychaetes) can feed directly on this organic matter [135], which is then stored as tissue or re-mineralized back to the water column. Because of their high densities and biomass, RBP often filter large volumes of water and cause declines of phytoplankton biomass, increasing water transparency [51], recycling nutrients, and mitigating effects of eutrophication in coastal marine environments [114]. RBP also strongly alter the habitat available for other organisms. The main impacts on this supporting service occur via changes in habitat quality caused by the RBP that modify the trophic structure of the community. Reef systems exert a significant structuring influence on benthic communities (increase abundance, richness, and diversity of infauna [129]).

\section{Synthesis and Future Directions}

This review shows how ecosystem engineering polychaetes that build reefs can control ecosystem processes and affect habitat quality, thus regulating community structure, ecosystem functioning, and the provision of ecosystem services. In general, polychaete reefs have positive impacts on the diversity and abundance of many species mediated by reef structures [33,34], but there can be exceptions [36]. Biogenic reefs are usually biodiversity hotspots because they have higher species diversity than surrounding habitats. However, RBP do not contain many novel species but have high density and biomass of the native infaunal organisms [33,53].

Abiotic changes induced by physical engineering activity can cause biotic changes. Filter feeding and biodeposition modify the physical environment (e.g., increased water transparency [51]). By feeding on phytoplankton and decreasing water turbidity, filter-feeding RBP can control primary production [39,51,52], increase light penetration [51], and can mitigate eutrophication [114]. The biodeposits generated by these RBP can be retained in the benthic environment, thus enhancing the benthic-pelagic coupling [55]. Consequently, the reefs generate hotspots for benthic primary production, which seems to be a general attribute of RBP [37,55].

Ecosystem engineers make manifold contributions to ecosystem services [129], and RBP are no exception. I believe a number of gaps in knowledge regarding RBP ecosystem services need to be 
addressed. A central goal should be to quantify in which ways reef-building, filter-feeding polychaetes are affecting ecosystem services worldwide. Linking changes in habitat structure with reef production, filter-feeding activities, and biodeposition to ecosystem services is essential for effective management decisions, preservation, and restoration of natural systems.

Funding: The author was funded by the Consejo Nacional de Investigaciones Científicas y Técnicas (CONICET, Argentina).

Acknowledgments: Thanks to J. Alberti for his help in writing the manuscript, and Camila and Clarita for helping me with language edition and with the map. I also thank two anonymous referees for their suggestions and J.L. Gutiérrez for his valuable comments as editor.

Conflicts of Interest: The author declares no conflict of interest.

\section{References}

1. Power, M.E. Ecosystem engineering by organisms: Why semantics matters Reply from M. Power. Trends Ecol. Evol. 1997, 12, 275-276. [CrossRef]

2. Wright, J.P.; Jones, C.G. The Concept of Organisms as Ecosystem Engineers Ten Years On: Progress, Limitations, and Challenges. BioScience 2006, 56, 203-209. [CrossRef]

3. Jones, C.; Lawton, J.; Shachak, M. Organisms as ecosystem engineers. Oikos 1994, 69, 373-386. [CrossRef]

4. Jones, C.; Lawton, J.; Shachak, M. Positive and negative effects of organisms as physical ecosystem engineers. Ecology 1997, 78, 1946-1957. [CrossRef]

5. Jones, C.G.; Gutiérrez, J.L.; Byers, J.E.; Crooks, J.A.; Lambrinos, J.G.; Talley, T.S. A framework for understanding physical ecosystem engineering by organisms. Oikos 2010, 119, 1862-1869. [CrossRef]

6. Gutierrez, J.L.; Jones, C.G.C.; Strayer, D.L.; Iribarne, O.O. Mollusks as ecosystem engineers: The role of shell production in aquatic habitats. Oikos 2003, 101, 79-90. [CrossRef]

7. Lambrinos, J.G.; Bando, K.J. Habitat modification inhibits conspecific seedling recruitment in populations of an invasive ecosystem engineer. Biol. Invasions 2008, 10, 729-741. [CrossRef]

8. Angelini, C.; Silliman, B.R. Secondary foundation species as drivers of trophic and functional diversity: Evidence from a tree-epiphyte system. Ecology 2014, 95, 185-196. [CrossRef]

9. Fanjul, E.; Escapa, M.; Montemayor, D.; Addino, M.; Alvarez, M.F.; Grela, M.A.; Iribarne, O. Effect of crab bioturbation on organic matter processing in South West Atlantic intertidal sediments. J. Sea Res. 2015, 95, 206-216. [CrossRef]

10. Wright, J.P.; Jones, C.G.; Flecker, A.S. An ecosystem engineer, the beaver, increases species richness at the landscape scale. Evolution 2002, 96-101. [CrossRef]

11. Crooks, J. Characterizing ecosystem-level consequences of biological invasions: The role of ecosystem engineers. Oikos 2002, 2, 153-166. [CrossRef]

12. van de Koppel, J.; van der Heide, T.; Altieri, A.H.; Eriksson, B.K.; Bouma, T.J.; Olff, H.; Silliman, B.R. Long-distance interactions regulate the structure and resilience of coastal ecosystems. Annu. Rev. Mar. Sci. 2015, 7, 139-158. [CrossRef] [PubMed]

13. Borthagaray, A.I.; Carranza, A. Mussels as ecosystem engineers: Their contribution to species richness in a rocky littoral community. Acta Oecol. 2007, 31, 243-250. [CrossRef]

14. Wright, J.; Jones, C. Predicting effects of ecosystem engineers on patch-scale species richness from primary productivity. Ecology 2008, 85, 2071-2081. [CrossRef]

15. Haussmann, N.S.; Louw, M.A.; Lewis, S.; Nicol, K.J.H.; van der Merwe, S.; le Roux, P.C. Ecosystem engineering through aardvark (Orycteropus afer) burrowing: Mechanisms and effects. Ecol. Eng. 2018, 118, 66-72. [CrossRef]

16. Johnston, C.A.; Naiman, R.J. Aquatic Patch Creation in Relation to Beaver Population Trends. Ecology 1990, 71, 1617-1621. [CrossRef]

17. Zhang, Q.; Zak, J.C. Effects of Gap Size on Litter Decomposition and Microbial Activity in a Subtropical Forest. Ecology 1995, 76, 2196-2204. [CrossRef]

18. Froz, J.; Kalčík, J.; Cudlín, P. Accumulation of phosphorus in nests of red wood ants Formica s. str. Ann. Zool. Fenn. 2005, 42, 269-275. 
19. Commito, J.A.; Como, S.; Grupe, B.M.; Dow, W.E. Species diversity in the soft-bottom intertidal zone: Biogenic structure, sediment, and macrofauna across mussel bed spatial scales. J. Exp. Mar. Biol. Ecol. 2008, 366, 70-81. [CrossRef]

20. Passarelli, C.; Olivier, F.; Paterson, D.M.; Meziane, T.; Hubas, C. Organisms as cooperative ecosystem engineers in intertidal flats. J. Sea Res. 2014, 92, 92-101. [CrossRef]

21. Bertness, M.D.; Leonard, G.H. The role of positive interactions in communities: Lessons from intertidal habitats. Ecology 1997, 78, 1976-1989. [CrossRef]

22. Gutiérrez, J.; Iribarne, O. Role of Holocene beds of the stout razor clam Tagelus plebeius in structuring present benthic communities. Mar. Ecol. Prog. Ser. 1999, 185, 213-228. [CrossRef]

23. Escapa, M.; Isaacch, J.P.; Daleo, P.; Iribarne, O.; Borges, M.; Santos, E.P.D.; Gagliardini, D.A.; Lasta, M. The distribution and ecological effects of the introduced Pacific oyster Crassostrea gigas (Thunberg, 1793) in Northern Patagonia. J. Shell. Res. 2004, 23, 765-772.

24. Ruesink, J.L.; Lenihan, H.S.; Trimble, A.C.; Heiman, K.W.; Micheli, F.; Byers, J.E.; Kay, M.C. Introduction of non-native oysters: Ecosystem effects and restoration implications. Annu. Rev. Ecol. Evol. Syst. 2005, 36, 643-689. [CrossRef]

25. Berkenbusch, K.; Rowden, A.A. An examination of the spatial and temporal generality of the influence of ecosystem engineers on the composition of associated assemblages. Aquat. Ecol. 2007, 41, 129-147. [CrossRef]

26. Chapman, N.D.; Moore, C.G.; Harries, D.B.; Lyndon, A.R. The community associated with biogenic reefs formed by the polychaete, Serpula vermicularis. J. Mar. Biol. Assoc. U. K. 2012, 92, 679-685. [CrossRef]

27. Vitousek, P.M.P.M. Biological invasions and ecosystem processes: Towards an integration of population biology and ecosystem studies. Oikos 1990, 57, 7-13. [CrossRef]

28. Petersen, B.; Exo, K.K.; Klaus-Michael, E.; Petersenl, B.; Exo, K.K. Predation of waders and gulls on Lanice conchilega tidal flats in the Wadden Sea. Mar. Ecol. Prog. Ser. 1999, 178, 229-240. [CrossRef]

29. Bruschetti, M.; Bazterrica, C.; Luppi, T.; Iribarne, O. An invasive intertidal reef-forming polychaete affect habitat use and feeding behavior of migratory and locals birds in a SW Atlantic coastal lagoon. J. Exp. Mar. Biol. Ecol. 2009, 375, 76-83. [CrossRef]

30. Duarte, C.M.; Chiscano, C.L. Seagrass biomass and production: A reassessment. Aquat. Bot. 1999, 65, $159-174$. [CrossRef]

31. Schwindt, E.; Iribarne, O.O.; Isla, F.I. Physical effects of an invading reef-building polychaete on an Argentinean estuarine environment. Estuar. Coast. Shelf Sci. 2004, 59, 109-120. [CrossRef]

32. Jaubet, M.L.; de los Ángeles Sánchez, M.; Rivero, M.S.; Garaffo, G.V.; Vallarino, E.A.; Elías, R. Intertidal biogenic reefs built by the polychaete Boccardia proboscidea in sewage-impacted areas of Argentina, SW Atlantic. Mar. Ecol. 2011, 32, 188-197. [CrossRef]

33. Dubois, S.; Commito, J.A.; Olivier, F.; Retière, C.; Retiere, C. Effects of epibionts on Sabellaria alveolata (L.) biogenic reefs and their associated fauna in the Bay of Mont Saint-Michel. Estuar. Coast. Shelf Sci. 2006, 68, 635-646. [CrossRef]

34. Schwindt, E.; Bortolus, A.; Iribarne, O.O. Invasion of a reef-builder polychaete: Direct and indirect impacts on the native benthic community structure. Biol. Invasions 2001, 3, 137-149. [CrossRef]

35. Zühlke, R. Polychaete tubes create ephemeral community patterns: Lanice conchilega (Pallas, 1766) associations studied over six years. J. Sea Res. 2001, 46, 261-272. [CrossRef]

36. Elías, R.; Jaubet, M.L.; Llanos, E.N.; Sanchez, M.A.; Rivero, M.S.; Garaffo, G.V.; Sandrini-Neto, L. Effect of the invader Boccardia proboscidea (Polychaeta: Spionidae) on richness, diversity and structure of SW Atlantic epilithic intertidal community. Mar. Pollut. Bull. 2015, 91, 530-536. [CrossRef] [PubMed]

37. Jones, A.G.; Dubois, S.F.; Desroy, N.; Fournier, J. Interplay between abiotic factors and species assemblages mediated by the ecosystem engineer Sabellaria alveolata (Annelida: Polychaeta). Estuar. Coast. Shelf Sci. 2018, 200, 1-18. [CrossRef]

38. Sousa, R.; Gutiérrez, J.; Aldridge, D. Non-indigenous invasive bivalves as ecosystem engineers. Biol. Invasions 2009, 11, 2367-2385. [CrossRef]

39. Dubois, S.; Barillé, L.; Cognie, B. Feeding response of the polychaete Sabellaria alveolata (Sabellariidae) to changes in seston concentration. J. Exp. Mar. Biol. Ecol. 2009, 376, 94-101. [CrossRef]

40. Cugier, P.; Struski, C.; Blanchard, M.; Mazurié, J.; Pouvreau, S.; Olivier, F.; Trigui, J.R.J.R.; Thiébaut, E. Assessing the role of benthic filter feeders on phytoplankton production in a shellfish farming site: Mont Saint Michel Bay, France. J. Mar. Syst. 2010, 82, 21-34. [CrossRef] 
41. Wilson, D.P. Sabellaria Colonies at Duckpool, North Cornwall, 1961-1970. J. Mar. Biol. Assoc. U. K. 1971, 51, 509-580. [CrossRef]

42. Lecornu, B.; Schlund, E.; Basuyaux, O.; Cantat, O.; Dauvin, J.-C. Dynamics (from 2010-2011 to 2014) of Sabellaria alveolata reefs on the western coast of Cotentin (English Channel, France). Reg. Stud. Mar. Sci. 2016, 8, 157-169. [CrossRef]

43. Bonifazi, A.; Ventura, D.; Mancini, E. Sabellaria reefs as reservoirs of preferential species: The case of Eulalia ornata Saint-Joseph, 1888 (Annelida: Phyllodocidae). Mar. Freshw. Res. 2018, 69, 1635-1640. [CrossRef]

44. Stone, R.; Callaway, R.; Bull, J.C. Are biodiversity offsetting targets of ecological equivalence feasible for biogenic reef habitats? Ocean Coast. Manag. 2019, 177, 97-111. [CrossRef]

45. Gravina, M.F.; Cardone, F.; Bonifazi, A.; Bertrandino, M.S.; Chimienti, G.; Longo, C.; Marzano, C.N.; Moretti, M.; Lisco, S.; Moretti, V.; et al. Sabellaria spinulosa (Polychaeta, Annelida) reefs in the Mediterranean sea: Habitat mapping, dynamics and associated fauna for conservation management. Estuar. Coast. Shelf Sci. 2018, 200, 248-257. [CrossRef]

46. van der Reijden, K.J.; Koop, L.; O’Flynn, S.; Garcia, S.; Bos, O.; van Sluis, C.; Maaholm, D.J.; Herman, P.M.J.; Simons, D.G.; Olff, H.; et al. Discovery of Sabellaria spinulosa reefs in an intensively fished area of the Dutch continental shelf, North sea. J. Sea Res. 2019, 144, 85-94. [CrossRef]

47. Lisco, S.; Moretti, M.; Moretti, V.; Cardone, F.; Corriero, G.; Longo, C. Sedimentological features of Sabellaria spinulosa biocontructions. Mar. Pet. Geol. 2017, 87, 203-212. [CrossRef]

48. Ataide, M.B.; Venekey, V.; Filho, J.S.R.; dos Santos, P.J.P. Sandy reefs of Sabellaria wilsoni (Polychaeta: Sabellariidae) as ecosystem engineers for meiofauna in the Amazon coastal region, Brazil. Mar. Biodivers. 2014, 44, 403-413. [CrossRef]

49. Dong, Z.; Sun, T.; Wang, L. The biogenic reefs formed by the alien polychaete Hydroides dianthus (Serpulidae, Annelida) favor the polyp stage of Aurelia coerulea (Cnidaria, Scyphozoa) in a coastal artificial lake. Mar. Pollut. Bull. 2018, 129, 86-91. [CrossRef]

50. Davies, B.R.; Stuart, V.; de Villiers, M. The filtration activity of a serpulid polychaete population (Ficopomatus enigmaticus (Fauvel) and its effects on water quality in a coastal marina. Estuar. Coast. Shelf Sci. 1989, 29, 613-620. [CrossRef]

51. Bruschetti, M.; Luppi, T.; Fanjul, E.; Rosenthal, A.; Iribarne, O. Grazing effect of the invasive reef-forming polychaete Ficopomatus enigmaticus (Fauvel) on phytoplankton biomass in a SW Atlantic coastal lagoon. J. Exp. Mar. Biol. Ecol. 2008, 354, 212-219. [CrossRef]

52. Pan, J.; Marcoval, M.A. Top-down effects of an exotic serpulid polychaete on natural plankton assemblage of estuarine and brackish systems in the SW Atlantic. J. Coast. Res. 2014, 30, 1226-1235. [CrossRef]

53. Heiman, K.; Vidargas, N.; Micheli, F. Non-native habitat as home for non-native species: Comparison of communities associated with invasive tubeworm and native oyster reefs. Aquat. Biol. 2008, 2, 47-56. [CrossRef]

54. Bazterrica, M.C.; Botto, F.; Iribarne, O.O. Effects of an invasive reef-building polychaete on the biomass and composition of estuarine macroalgal assemblages. Biol. Invasions 2012, 14, 765-777. [CrossRef]

55. Bruschetti, M.; Bazterrica, C.; Fanjul, E.; Luppi, T.; Iribarne, O.; Fanjul, M.E.; Luppi, T.; Iribarne, O. Effect of biodeposition of an invasive polychaete on organic matter content and productivity of the sediment in a coastal lagoon. J. Sea Res. 2011, 66, 20-28. [CrossRef]

56. Garaffo, G.V.; Jaubet, M.L.; Sánchez, M.D.L.Á.; Rivero, M.S.; Vallarino, E.A.; Elías, R. Sewage-induced polychaete reefs in a SW Atlantic shore: Rapid response to small-scale disturbance. Mar. Ecol. 2012, 33, 272-279. [CrossRef]

57. Jaubet, M.L.; Garaffo, G.V.; Sánchez, M.A.; Elías, R. Reef-forming polychaetes outcompetes ecosystem engineering mussels. Mar. Pollut. Bull. 2013, 71, 216-221. [CrossRef] [PubMed]

58. Callaway, R.; Desroy, N.; Dubois, S.F.; Fournier, J.; Frost, M.; Godet, L.; Hendrick, V.J.; Rabaut, M. Ephemeral bio-engineers or reef-building polychaetes: How stable are aggregations of the tube worm Lanice conchilega (Pallas, 1766)? Integr. Comp. Biol. 2010, 50, 237-250. [CrossRef] [PubMed]

59. Rabaut, M.; Van de Moortel, L.; Vincx, M.; Degraer, S. Biogenic reefs as structuring factor in Pleuronectes platessa (Plaice) nursery. J. Sea Res. 2010, 64, 102-106. [CrossRef]

60. Alves, R.M.S.; Vanaverbeke, J.; Bouma, T.J.; Guarini, J.-M.; Vincx, M.; Van Colen, C. Effects of temporal fluctuation in population processes of intertidal Lanice conchilega (Pallas, 1766) aggregations on its ecosystem engineering. Estuar. Coast. Shelf Sci. 2017, 188, 88-98. [CrossRef] 
61. Denis, L.; Desroy, N.; Ropert, M. Ambient flow velocity and resulting clearance rates of the terebellid polychaete Lanice conchilega (Pallas, 1766). J. Sea Res. 2007, 58, 209-219. [CrossRef]

62. Schwindt, E.; De Francesco, C.G.; Iribarne, O.O. Individual and reef growth of the invasive reef-building polychaete Ficopomatus Enigmaticus in a south-western Atlantic coastal lagoon. J. Mar. Biol. Assoc. U. K. 2004, 84, 987-993. [CrossRef]

63. McQuaid, K.A.; Griffiths, C.L. Alien reef-building polychaete drives long-term changes in invertebrate biomass and diversity in a small, urban estuary. Estuar. Coast. Shelf Sci. 2014, 138, 101-106. [CrossRef]

64. Van Hoey, G.; Guilini, K.; Rabaut, M.; Vincx, M.; Degraer, S. Ecological implications of the presence of the tube-building polychaete Lanice conchilega on soft-bottom benthic ecosystems. Mar. Biol. 2008, 154, 1009-1019. [CrossRef]

65. Chouikh, N.; Gillet, P.; Langston, W.J.; Cheggour, M.; Maarouf, A.; Mouabad, A. first investigation of the composition and spatial distribution of polychaete feeding guilds from essaouira protected coastal area (Atlantic coast of Morocco). Appl. Ecol. Environ. Res. 2019, 17, 3231-3249. [CrossRef]

66. Desroy, N.; Dubois, S.F.; Fournier, J.; Ricquiers, L.; Mao, P.L.; Guerin, L.; Gerla, D.; Rougerie, M.; Legendre, A. The conservation status of Sabellaria alveolata (L.) (Polychaeta: Sabellariidae) reefs in the bay of Mont-Saint-Michel. Aquat. Conserv. Mar. Freshw. Ecosyst. 2011, 21, 462-471. [CrossRef]

67. Hove, H.T.; Weerdenburg, J. A generic revision of the brackish-water serpulid Ficopomatus. ReVision 1978, 96-120.

68. Obenat, S.S.M.; Pezzani, S.E.S. Life cycle and population structure of the polychaete Ficopomatus enigmaticus (Serpulidae) in Mar Chiquita coastal lagoon, Argentina. Estuaries 1994, 17, 263. [CrossRef]

69. Porta, B.L.; Nicoletti, L. Sabellaria alveolata (Linnaeus) reefs in the central Tyrrhenian sea (Italy) and associated polychaete fauna. Zoosymposia 2009, 2, 527-536.

70. Dubois, S.; Retière, C.; Olivier, F. Biodiversity associated with Sabellaria alveolata (Polychaeta: Sabellariidae) reefs: Effects of human disturbances. J. Mar. Biol. Assoc. U. K. 2002, 82, 817-826. [CrossRef]

71. Gruet, Y. Spatio-temporal changes of sabellarian reefs built by the sedentary polychaete Sabellaria alveolata (Linné). Mar. Ecol. 1986, 7, 303-319. [CrossRef]

72. Bonifazi, A.; Lezzi, M.; Ventura, D.; Lisco, S.; Cardone, F.; Gravina, M.F. Macrofaunal biodiversity associated with different developmental phases of a threatened Mediterranean Sabellaria alveolata (Linnaeus, 1767) reef. Mar. Environ. Res. 2019, 145, 97-111. [CrossRef] [PubMed]

73. Jackson, A. Sabellaria alveolata Honeycomb worm. In Marine Life Information Network: Biology and Sensitivity Key Information Reviews; Tyler-Walters, H., Hiscock, K., Eds.; Marine Biological Association of the United Kingdom: Plymouth, UK, 2008; pp. 1-14.

74. Aviz, D.; Silva, R.F.D.; Filho, J.S.R. Sabellaria wilsoni (Polychaeta: Sabellariidae): An ecosystem engineer and promoter of zoobenthos diversity in the Brazilian Amazon coast. J. Mar. Biol. Assoc. U. K. 2019, 99, 1099-1109. [CrossRef]

75. Moore, C.G.; Bates, C.R.; Mair, J.M.; Saunders, G.R.; Harries, D.B.; Lyndon, A.R. Mapping serpulid worm reefs (Polychaeta: Serpulidae) for conservation management. Aquat. Conserv. Mar. Freshw. Ecosyst. 2009, 19, 226-236. [CrossRef]

76. Read, G.; Gordon, D. Adventive occurrence of the fouling serpulid Ficopomatus enigmaticus (Polychaeta) in New Zealand. N. Z. J. Mar. Freshw. Res. 1991, 25, 269-273. [CrossRef]

77. Asakura, A. Recent introductions of marine benthos into Tokyo Bay (Review): Process of invasion into an urban ecosystem with discussion on the factors inducing their successful introduction. J. Nat. Hist. Mus. Inst. Chiba 1992, 2, 1-14.

78. Thorp, C.H. Population variation in Ficopomatus enigmaticus (Fauvel) (Polychaeta, Serpulidae) in a brackish water millpond at Emsworth, West Sussex, U.K. Mém Mus Natl Hist Nat Sér Zool 1994, 162, 585-591.

79. Bianchi, C.N.; Morri, C. Ficopomatus 'reefs in the Po river delta (Northern Adriatic): Their constructional dynamics, biology, and influence on the brackish-water biota. Mar. Ecol. 1996, 17, 51-66. [CrossRef]

80. Borthagaray, A.I.; Clemente, J.M.; Boccardi, L.; Brugnoli, E. Impacto potencial de invasión de Ficopomatus enigmaticus (Fauvel) (Polychaeta: Serpulidae) en la Laguna de Rocha, Uruguay. Pan-Am. J. 2006, 1, 57-65.

81. Link, H.; Nishi, E.; Tanaka, K.; Bastida-Zavala, R.; Kupriyanova, E.; Yamakita, T. Hydroides dianthus (Polychaeta: Serpulidae), an alien species introduced into Tokyo Bay, Japan. Mar. Biodivers. Rec. 2009, 1-6. [CrossRef] 
82. Toonen, R.J.; Pawlik, J.R. Foundations of gregariousness: A dispersal polymorphism among the planktonic larvae of a marine invertebrate. Evolution 2001, 55, 2439-2454. [CrossRef] [PubMed]

83. Hartman, O. Some contributions to the biology and life history of Spionidae from California. Allan Hancock Pac. Exped. 1941, 7, 289-323.

84. Bailey-Brock, J.H. A new record of the polychaete Boccardia proboscidea (Family Spionidae), imported to Hawai'i with oysters! Pac. Sci. 2000, 54, 4.

85. Sato-Okoshi, W. Polydorid species (Polychaeta: Spionidae) in Japan, with descriptions of morphology, ecology and burrow structure. 2. Non-boring species. J. Mar. Biol. Assoc. U. K. 2000, 80, 443-456. [CrossRef]

86. Hewitt, C.L.; Campbell, M.L.; Thresher, R.E.; Martin, R.B.; Boyd, S.; Cohen, B.F.; Currie, D.R.; Gomon, M.F.; Keough, M.J.; Lewis, J.A.; et al. Introduced and cryptogenic species in port Phillip bay, Victoria, Australia. Mar. Biol. 2004, 144, 183-202.

87. Martínez, J.; Adarraga, I.; López, E. New data of the genus Boccardia Carazzi, 1893 (Polychaeta: Spionidae) for the Iberian peninsula and the Atlantic ocean. Boletin Inst. Espanol Oceanogr. 2006, 22, 53-64.

88. Simon, C.A.; Worsfold, T.M.; Lange, L.; Sterley, J. The genus Boccardia (Polychaeta: Spionidae) associated with mollusc shells on the south coast of South Africa. J. Mar. Biol. Assoc. U. K. 2010, 90, 585-598. [CrossRef]

89. Becherucci, M.E.; Jaubet, M.L.; Saracho Bottero, M.A.; Llanos, E.N.; Elías, R.; Garaffo, G.V. Rapid sewage pollution assessment by means of the coverage of epilithic taxa in a coastal area in the SW Atlantic. Sci. Total Environ. 2018, 628-629, 826-834. [CrossRef]

90. Rabaut, M.; Vincx, M.; Degraer, S. Do Lanice conchilega (sandmason) aggregations classify as reefs? Quantifying habitat modifying effects. Helgol. Mar. Res. 2009, 63, 37-46. [CrossRef]

91. De Smet, B.; D’Hondt, A.S.; Verhelst, P.; Fournier, J.; Godet, L.; Desroy, N.; Rabaut, M.; Vincx, M.; Vanaverbeke, J. Biogenic reefs affect multiple components of intertidal soft-bottom benthic assemblages: The Lanice conchilega case study. Estuar. Coast. Shelf Sci. 2015, 152, 44-55. [CrossRef]

92. Dodd, J.; Baxter, L.; Hughes, D.J. Mapping Serpula vermicularis (Polychaeta: Serpulidae) aggregations in Loch Teacuis, western Scotland, a new record. Mar. Biol. Res. 2009, 5, 200-205. [CrossRef]

93. Bazterrica, M.C.; Alvarez, M.F.; Bruschetti, C.M.; Hidalgo, F.J.; Fanjul, M.E.; Iribarne, O.; Botto, F. Factors controlling macroalgae assemblages in a Southwest Atlantic coastal lagoon modified by an invading reef forming polychaete. J. Exp. Mar. Biol. Ecol. 2013, 443, 169-177. [CrossRef]

94. Luppi, T.A.; Bas, C.C. The role of the invasive polychaete Ficopomatus enigmaticus Fauvel 1923 (Polychaeta: Serpulidae) reefs in the recruitment of Cyrtograpsus angulatus Dana 1851 (Brachyura: Grapsidae), in the Mar Chiquita coastal lagoon, Argentin. Cienc. Mar. 2002, 28, 319-330. [CrossRef]

95. Obenat, S.; Spivak, E.; Garrido, L. Life history and reproductive biology of the invasive amphipod Melita palmata (Amphipoda: Melitidae) in the Mar Chiquita coastal lagoon, Argentina. J. Mar. Biol. Assoc. U. K. 2006, 86, 1381. [CrossRef]

96. Rabaut, M.; Guilini, K.; Van Hoey, G.; Vincx, M.; Degraer, S. A bio-engineered soft-bottom environment: The impact of Lanice conchilega on the benthic species-specific densities and community structure. Estuar. Coast. Shelf Sci. 2007, 75, 525-536. [CrossRef]

97. Badano, E.E.I.; Villarroel, E.; Bustamante, R.R.O.; Marquet, P.A.; Cavieres, L.A. Ecosystem engineering facilitates invasions by exotic plants in high-Andean ecosystems. J. Ecol. 2007, 95, 682-688. [CrossRef]

98. Llanos, E.N.; Becherucci, M.E.; Garaffo, G.V.; Vallarino, E.A. A shift of ecosystem engineers during the succession of an intertidal benthic community associated with natural and anthropogenic disturbances. Reg. Stud. Mar. Sci. 2019, 31, 100754. [CrossRef]

99. Bouma, T.J.; De Vries, M.B.; Herman, P.M.J. Comparing ecosystem engineering efficiency of two plant species with contrasting growth strategies. Ecology 2010, 91, 2696-2704. [CrossRef]

100. Newell, R.I.E.; Koch, E.W. Modeling seagrass density and distribution in response to changes in turbidity stemming from bivalve filtration and seagrass sediment stabilization. Estuaries 2004, 27, 793-806. [CrossRef]

101. Gutiérrez, J.L.; Jones, C.G.; Byers, J.E.; Arkema, K.K.; Berkenbusch, K.; Commito, J.A.; Duarte, C.M.; Hacker, S.D.; Lambrinos, J.G.; Hendriks, I.E.; et al. 7.04-Physical ecosystem engineers and the functioning of estuaries and coasts. In Treatise on estuarine and coastal science; Wolanski, E., McLusky, D., Eds.; Academic Press: Waltham, MA, USA, 2011; pp. 53-81.

102. Bailey-Brock, J.H. Sediment trapping by Chaetopterid polychaetes on a Hawaiian fringing reef. J. Mar. Res. $1979,37,643-656$. 
103. Murray, J.M.H.; Meadows, A.; Meadows, P.S. Biogeomorphological implications of microscale interactions between sediment geotechnics and marine benthos: A review. Geomorphology 2002, 47, 15-30. [CrossRef]

104. Braeckman, U.; Rabaut, M.; Vanaverbeke, J.; Degraer, S.; Vincx, M. Protecting the commons: The use of subtidal ecosystem engineers in marine management. Aquat. Conserv. Mar. Freshw. Ecosyst. 2014, 24, 275-286. [CrossRef]

105. Friedrichs, M.; Graf, G.; Springer, B. Skimming flow induced over a simulated polychaete tube lawn at low population densities. Mar. Ecol. Prog. Ser. 2000, 192, 219-228. [CrossRef]

106. Toupoint, N.; Godet, L.; Fournier, J.; Retière, C.; Olivier, F. Does Manila clam cultivation affect habitats of the engineer species Lanice conchilega (Pallas, 1766)? Mar. Pollut. Bull. 2008, 56, 1429-1438. [CrossRef]

107. Dame, R.; Spurrier, J.; Wolaver, T. Carbon, nitrogen and phosphorus processing by an oyster reef. Mar. Ecol. Prog. Ser. 1989, 54, 249-256. [CrossRef]

108. Zhu, B.; Fitzgerald, D.G.; Mayer, C.M.; Rudstam, L.G.; Mills, E.L. Alteration of ecosystem function by zebra mussels in Oneida lake: Impacts on submerged macrophytes. Ecosystems 2006, 9, 1017-1028. [CrossRef]

109. Jordana, E.; Charles, F.; Grémare, A.; Amouroux, J.-M.; Chrétiennot-Dinet, M.-J. Food sources, ingestion and absorption in the suspension-feeding polychaete, Ditrupa arietina (O.F. Müller). J. Exp. Mar. Biol. Ecol. 2001, 266, 219-236. [CrossRef]

110. Dubois, S.; Barillé, L.; Retière, C. Efficiency of particle retention and clearance rate in the polychaete Sabellaria alveolata L. Comptes Rendus Biol. 2003, 326, 413-421. [CrossRef]

111. Riisgård, H. Efficiency of particle retention and filtration rate in 6 species of Northeast American bivalves. Mar. Ecol. Prog. Ser. 1988, 45, 217-223. [CrossRef]

112. Riisgård, H. On measurement of filtration rate in bivalves-the stony road to reliable data: Review and interpretation. Mar. Ecol. Prog. Ser. 2001, 211, 275-291. [CrossRef]

113. Dame, R.; Prins, T. Bivalve carrying capacity in coastal ecosystems. Aquat. Ecol. 1997, 31, 409-421. [CrossRef]

114. Bruschetti, C.M.; Addino, M.; Luppi, T.; Iribarne, O. Effects of nutrient enrichment and grazing by an invasive filter feeder on phytoplankton biomass in a South West Atlantic coastal lagoon. Biol. Invasions 2018, 20, 2245-2256. [CrossRef]

115. Collin, A.; Dubois, S.; Ramambason, C.; Etienne, S. Very high-resolution mapping of emerging biogenic reefs using airborne optical imagery and neural network: The honeycomb worm (Sabellaria alveolata) case study. Int. J. Remote Sens. 2018, 39, 5660-5675. [CrossRef]

116. Stutes, A.; Cebrian, J.; Corcoran, A. Effects of nutrient enrichment and shading on sediment primary production and metabolism in eutrophic estuaries. Mar. Ecol. Prog. Ser. 2006, 312, 29-43. [CrossRef]

117. Pratt, D.R.; Pilditch, C.A.; Lohrer, A.M.; Thrush, S.F. The effects of short-term increases in turbidity on sandflat microphytobenthic productivity and nutrient fluxes. J. Sea Res. 2014, 92, 170-177. [CrossRef]

118. Forster, R.; Créach, V.; Sabbe, K.; Vyverman, W.; Stal, L. Biodiversity-Ecosystem function relationship in microphytobenthic diatoms of the Westerschelde estuary. Mar. Ecol. Prog. Ser. 2006, 311, 191-201. [CrossRef]

119. Moncreiff, C.A.; Sullivan, M.J.; Daehnick, A.E. Primary production dynamics in seagrass beds of Mississippi Sound: The contributions of seagrass, epiphytic algae, sand microflora, and phytoplankton. Mar. Ecol. Prog. Ser. 1992, 87, 161-171. [CrossRef]

120. MacIntyre, H.; Geider, R.; Miller, D. Microphytobenthos: The ecological role of the "secret garden" of unvegetated, shallow-water marine habitats. I. Distribution, abundance and primary production. Estuaries Coasts 1996, 19. [CrossRef]

121. Botto, F.; Valiela, I.; Iribarne, O.; Martinetto, P.; Alberti, J. Impact of burrowing crabs on C and N sources, control, and transformations in sediments and food webs of SW Atlantic estuaries. Mar. Ecol. Prog. Ser. 2005, 293, 155-164. [CrossRef]

122. Martinetto, P.; Valinas, M.; Palomo, G.; Iribarne, O.; Valiñas, M.; Palomo, G.; Iribarne, O. Negative interactions between two SW Atlantic intertidal crabs in soft-bottom habitats. Mar. Biol. 2007, 151, 1479-1490. [CrossRef]

123. Wotton, R.S.; Malmqvist, B. Feces in aquatic ecosystems feeding animals transform organic matter into fecal pellets, which sink or are transported horizontally by currents; these fluxes relocate organic matter in aquatic ecosystems. BioScience 2001, 51, 537-544. [CrossRef]

124. Kooijman, S. Pseudo-faeces production in bivalves. J. Sea Res. 2006, 56, 103-106. [CrossRef]

125. Giles, H.; Pilditch, C. Effects of diet on sinking rates and erosion thresholds of mussel Perna canaliculus biodeposits. Mar. Ecol. Prog. Ser. 2004, 282, 205-219. [CrossRef] 
126. Kautsky, N.; Evans, S. Role of biodeposition by Mytilus edulis in the circulation of matter and nutrients in a Baltic coastal ecosystem. Mar. Ecol. Prog. Ser. 1987, 38, 201-212. [CrossRef]

127. Dubois, S.; Barillé, L.; Cognie, B.; Beninger, P.P.G. Particle capture and processing mechanisms in Sabellaria alveolata (Polychaeta: Sabellariidae). Mar. Ecol. Prog. Ser. 2005, 301, 159-171. [CrossRef]

128. Turner, R.K.; Georgiou, S.; Fisher, B. Valuing Ecosystem Services: The Case of Multi-Functional Wetlands; Routledge: London, UK, 2008; ISBN 978-1-84407-615-4.

129. Gutierrez, J.L. Modification of habitat quality by non-native species Impact of Biological Invasions on Ecosystem Services. In Impact of Biological Invasions on Ecosystem Services; Springer International Publishing: Berlin/Heidelberg, Germany, 2017; pp. 33-47.

130. Masselink, G.; Russell, P. Impacts of climate change on coastal erosion. MCCIP Sci. Rev. 2013, 71-86. [CrossRef]

131. Pandolfi, J.M.; Ross Robertson, D.; Kirtley, D.W. Roles for worms in reef-building. Coral Reefs 1998, 17, 120. [CrossRef]

132. Grabowski, J.H.; Brumbaugh, R.D.; Conrad, R.F.; Keeler, A.G.; Opaluch, J.J.; Peterson, C.H.; Piehler, M.F.; Powers, S.P.; Smyth, A.R. Economic valuation of ecosystem services provided by oyster reefs. BioScience 2012, 62, 900-909. [CrossRef]

133. Gracia, A.; Rangel-Buitrago, N.; Oakley, J.A.; Williams, A.T. Use of ecosystems in coastal erosion management. Ocean Coast. Manag. 2018, 156, 277-289. [CrossRef]

134. Fenchel, T. Marine Plankton Food Chains. Annu. Rev. Ecol. Syst. 1988, 19, 19-38. [CrossRef]

135. Zhou, Y.; Yang, H.; Zhang, T.; Liu, S.; Zhang, S.; Liu, Q.; Xiang, J.; Zhang, F. Influence of filtering and biodeposition by the cultured scallop Chlamys farreri on benthic-pelagic coupling in a eutrophic bay in China. Mar. Ecol. Prog. Ser. 2006, 317, 127-141. [CrossRef]

(C) 2019 by the author. Licensee MDPI, Basel, Switzerland. This article is an open access article distributed under the terms and conditions of the Creative Commons Attribution (CC BY) license (http://creativecommons.org/licenses/by/4.0/). 